Journal of American Studies, 55 (2021), 5, 991-101 8

(C) The Author(s), 202 r. Published by Cambridge University Press in association with the British Association for American Studies. This is an Open Access article, distributed under the terms of the Creative Commons Attribution licence (http://creativecommons.org/licenses/by/4.o/), which permits unrestricted re-use, distribution, and reproduction in any medium, provided the original work is properly cited.

doi:10.1017/S0021875820001735 First published online or April 2021

\title{
"We Chilluns, Long wid Her, Wuz Lak de Udder Slaves": Free Black Families and Quasi-slavery in the Late Antebellum Era
}

\section{EMILY WEST (1)}

This article shows how and why some free black families ended up living among the enslaved in the late antebellum era. Enslavers brought free people of colour into forms of informal quasislavery that differed little from enslavement despite their free legal status. Despite a lack of evidence, piecing together free blacks' experiences through surviving sources reveals much about the porous boundary between slavery and freedom where enslavers manipulated marginality for financial gain. There was no sharp delineation between slavery and freedom but instead a continuum of oppression characterized by varying degrees of persecution and fragile freedoms.

That Emma Stone, a Works Progress Administration (WPA) interviewee, quoted above, believed she was "lak udder slaves" despite being legally free reveals much about the ambiguity of status for free black children (and sometimes their parents) who lived in the southern United States in the late antebellum era. Stone, her nine siblings and her mother all lived on the Bell family plantation in Chatham County, North Carolina, where Stone's enslaved father, Edmund Bell, also resided. ${ }^{\mathrm{S}}$ Stone was not legally enslaved because all free black women's children were legally free in the antebellum era, regardless of their fathers' status, unlike those born to free black men and enslaved mothers. But in this case, Stone's father's enslaver seems to have paid scant attention to the law, and simply treated her mother and her ten children as though they belonged to him as enslaved people.

History Department, University of Reading. Email: e.r.west@reading.ac.uk.

${ }^{1}$ Emma Stone, Federal Writers Project: Slave Narrative Project, Vol. I I, North Carolina, Part 2 (Jackson-Yellerday) 329. All electronically available interviews with WPA respondents have been accessed via the Library of Congress website at www.loc.gov/collections/ slave-narratives-from-the-federal-writers-project-1 936 6-to- 1938 /about-this-collection. 
This article explores the precarious position of free black families in the late antebellum South who lived among wider enslaved communities in order to convey the ways in which some free people of colour, especially those in poverty or with affective ties to the enslaved, lived in forms of quasi- or informal slavery despite their legal status. They lived as though they were enslaved despite their legal status as free. Free people of colour lived on the "edges," or margins, of the slave regime and illustrate that there was no sharp delineation between slavery and freedom but instead a continuum of oppression characterized by varying degrees of persecution. ${ }^{2}$ Moreover, these informal forms of servitude, so often absent from the historical record, are more common than has hitherto been recognized, and the lives of these free black and enslaved families had more parallels than differences because the legal status of freedom held little resonance for free black families living among the enslaved.

Undertaking detailed research into the lives of free people of colour in the late antebellum era, this article provides a case study of the fragile nature of freedom for free black families, and the dangers that informal association with white enslavers might bring. It illustrates how members of white households perceived local free black families as possessions that could be informally be brought into the system of enslavement in a relatively easy way, without resource to legal action. Some free people of colour hence found themselves in a highly vulnerable situation as the Civil War approached because proslavery advocates increasingly mooted the notion that all southern free blacks should become enslaved and their racial ideologies were gaining significant momentum. Laws directed against free people of colour hence grew harsher over the course of the antebellum era.

Not all black people in the US South were enslaved. Free people of colour existed because enslavers manumitted some slaves (although state legislatures increasingly legislated against this over time), while others were descended from free black women, and had never been enslaved. Virginia was the first American colony to enact a hereditary slavery law dictating that offspring should follow the status of their mother (partus sequitur ventrem) as enslaved in 1662, a law soon adopted elsewhere in British North America. The

2 On the "edges" of slavery see Peter Parish, Slavery: History and Historians (New York: Harper and Row, I989), I I I; and Parish, "The Edges of Slavery in the Old South: Or, Do Exceptions Prove Rules?", Slavery and Abolition, 4, I (1983), 106-25. On the idea of a spectrum of bondage and freedom see Emily West, Family or Freedom: People of Color in the Antebellum South (Lexington: University Press of Kentucky, 201 2), 6. Like Martha $S$. Jones, I use the terms "free people of colour" and "free blacks" interchangeably in order to keep my prose varied. Like her, I use the term "free" to indicate legal status only. See Martha S. Jones, Birthright Citizens: A History of Race and Rights in Antebellum America (Cambridge and New York: Cambridge University Press, 20 I8), I 64 n. 6. 
legislation led to the establishment of a "dual exploitation" of enslaved women as labourers and reproducers, a system that became entrenched by antebellum times, especially following the closing of the international slave trade in January i 808, after which reproduction became the easiest way for enslavers to increase their supply of chattel. ${ }^{3}$ By i 860 , free blacks numbered around a quarter of a million, compared to around four million enslaved people. ${ }^{4}$

Southern states as a whole denied free blacks legal citizenship despite their status as free, and they occupied an uneasy and sometimes complex legal position as neither citizens nor slaves, as a people policed through restrictive local legislation that sought to control nearly every aspect of their everyday lives. ${ }^{5}$ But it can be hard to find out about free black lives from their own perspectives. Some historians have found it easier to trace the lives of free people of colour in urban contexts than in rural ones, especially when writing about women. Others have examined the lives of free people of colour living within their own discrete communities away from white enslavers. ${ }^{6}$ However, this work instead focusses on the lives of free people of colour, many of whom were young, enmeshed within wider enslaved communities within the homes, farms and plantations of white enslavers, largely in rural contexts, and subject to slaveholders' power and control. Free people of colour constituted an important margin of the slave regime that highlights the whole and it is also significant that, as noted by Ira Berlin, the legislative

${ }^{3}$ For more on the evolution of partus sequitur ventrem see Jennifer Morgan, "Partus Sequitur Ventrem: Law, Race, and Reproduction in Colonial Slavery," Small Axe, 22, I (2018), I-17.

${ }^{4}$ Parish, Slavery, 107.

5 William J. Novak writes about the plethora of local laws and policing in The People's Welfare: Law and Regulation in Nineteenth-Century America (Chapel Hill: University of North Carolina Press, 1996), esp. I 3-I 5. Martha S. Jones, I 2, notes that "citizenship has a piecemeal quality in antebellum America, defined only as needed." This work concurs with that view.

${ }^{6}$ Key and more recent works on free people of colour in urban communities include Jones; Michael P. Johnson and James L. Roark, No Chariot Let Down: Charleston's Free People of Color on the Eve of the Civil War (New York: Norton, 1984); Suzanne Lebsock, The Free Women of Petersburg: Status and Culture in a Southern Town, 1784-I860 (New York: Norton, 1985); Jessica Millward, Finding Charity's Folk: Enslaved and Free Black Women in Maryland (Athens: University of Georgia Press, 2015); Amrita Chakrabarti Myers, Forging Freedom: Black Women and the Pursuit of Liberty in Antebellum Charleston (Chapel Hill: University of North Carolina Press, 201 I); Judith Kelleher Schafer, Becoming Free, Remaining Free: Manumission and Enslavement in New Orleans, 1846-1962 (Baton Rouge: Louisiana State University Press, 2003). Research on more discrete or isolated free black communities includes David W. Dangerfield, "Turning the Earth: Free Black Yeomanry in the Antebellum South Carolina Lowcountry," Agricultural History, 89, 2 (Spring 2015), 200-24; Billy D. Higgins, "The Origins and Fate of the Marion County Free Black Community," Arkansas Historical Quarterly, 54 (Winter 1995), 427-43; Gary B. Mills, The Forgotten People: Cane River's Creoles of Color (Baton Rouge: Louisiana State University Press, 2013; first published 1977). 
regulation of free black lives in the South provides clues about the later mechanics of Jim Crow segregation after Reconstruction ended. Berlin sees the origins of various post-Emancipation racial institutions such as the black codes, sharecropping and segregation specifically in antebellum legislation directed against free people of colour.7

There are significant methodological challenges inherent in researching free black people's lives during the era of enslavement, including those who were young, because the experiences and understandings of childhood are culturally constructed across time and space. Enslaved and free black children had limited "childhoods" because enslavers manipulated their vulnerability, especially in the context of increasingly discriminatory legislation directed against free blacks over the course of the antebellum era. Slaveholders made use of informal, rather than legal, systems of apprenticeship that are often absent from the historical record. However, using a combination of evidence about the Lundy children of Mississippi along with extensive WPA testimony from and about free people of colour from across the South in the late antebellum era, this article considers how and why free black children (and sometimes their wider families) came to live among the enslaved.

The relative scarcity of source materials makes it difficult to explore the lives of free blacks in the antebellum US South. Constituting a much smaller percentage of the overall southern population than the enslaved, and mostly poor and illiterate, free people of colour left relatively little written testimony. Some free blacks petitioned county courts and state legislatures on various matters, collated by the Race and Slavery Petitions Project, which also includes various petitions about free people of colour. More evidence can be found in the US Census evidence, since this data included information about some free blacks, whereas enslaved people appear only namelessly, within lists known as "slave schedules." 8 Other free people of colour are described in the published autobiographies of enslaved or formerly enslaved people.? Only a handful of WPA respondents (of some 2,500 interviews) interviewed in the r 930 declared themselves to have been free during the slavery era, although many formerly enslaved interviewees mentioned their interactions

7 Ira Berlin, "Southern Free People of Color in the Age of William Johnson," Southern Quarterly, 43, 2 (2006), I0-I5.

8 The Race and Slavery Petitions Project at the University of North Carolina can be accessed at https://library.uncg.edu/slavery/petitions. The US Census (including slave schedules) is accessible via www.ancestry.com. However, as will be shown, some of the free people of colour considered here are missing from the Census schedules.

9 For example, Harriet Jacobs, enslaved in North Carolina, devoted a considerable amount of time in her autobiography to her beloved grandmother, a free black woman named Molly Horniblow. See Harriet Jacobs, Incidents in the Life of a Slave Girl: Written by Herself (Boston, I 86I), at http://docsouth.unc.edu/fpn/jacobs/jacobs.html. 
with free blacks. So it can be hard to uncover the contours of free people of colour's lives from their own perspectives. Wilma King writes that finding out "what free black women actually thought" and deciphering the feelings and attitudes of free children of colour, for whom written evidence can be even more scant, is harder still. ${ }^{\circ}$

However, using a combination of source materials, for example Census evidence and WPA testimony, it is possible to paint a more composite picture of the lives of free black children who lived among the enslaved. The evidence related to the Lundy family comes from the state of Mississippi. With its large cotton plantations and as an important destination for westward expansion, this state exemplified the heart of the late antebellum slave regime. However, testimony from WPA respondents interviewed in the 1930s about their lives in the late antebellum era comes from across the southern states, with some of this evidence coming from electronically available interviews, and some from the published supplementary series of The American Slave: A Composite Autobiography. ${ }^{11}$ Efforts were also made to trace these individuals and the white families they lived with via the 1860 Census. $^{12}$ Importantly, none of the free people of colour explored here via WPA testimony could be found on the 1860 Census as living in the households of white families, suggesting they simply assumed an invisibility more typically associated with enslaved people, and that the enslavers they lived with simply omitted to tell Census enumerators that they had free blacks living in their households or on their lands.

Overall, though, despite numerous methodological hurdles and the relative absence of evidence, historians can find out about free black people's lives by probing the interstices of surviving archival records, achievable through careful and detailed research, and sometimes by adding in a jot of speculation about individual motives in order to both read and overcome archival silences. This piece does not shy away from highlighting what we cannot know as well as what we can. It sometimes hypothesizes and makes assumptions, inspired by Stephanie Camp's call for the use of imagination, speculation and empathy where historical evidence is lacking. As Sarah Haley wrote when researching the lives of incarcerated black women in the Jim Crow South, speculation does not "remedy" archival gaps, but it can enable

${ }^{10}$ Wilma King, The Essence of Liberty: Free Black Women during the Slave Era (Columbia and London: University of Missouri Press, 2006), 31 .

${ }^{1}$ See George P. Rawick, The American Slave: A Composite Autobiography, Supplement Series I and 2 (Westport, CT: Greenwood Press, 1977-79).

${ }_{12}$ Gary B. Mills's The Forgotten People, xxvi, makes a strong case for researching narrower, smaller communities of free people of colour in order to access a wider variety of source materials in greater depth than is possible in broader geographical and temporal analyses. 
"historical musings" such as those expressed here. Likewise, inspired by the work of historian Erica Armstrong Dunbar, this work seeks to "tell the stories" of the lives of free black families living among the enslaved even when their own voices are lacking. ${ }^{13}$ Bringing their experiences to light adds depth and nuance to our understandings of the often complex machinations of the slave regime and how it affected the lives of those in close proximity to it.

The experiences of free black children also enlighten debates about the meanings of "childhood" for people both free and enslaved. Some free children of colour had an absence of "childhood" that contrasted with the lives of enslaved children. Childhood is culturally determined, rather than transhistoric, and within US slavery both enslavers and the enslaved accepted a notion of childhood as distinct from adulthood even though that experience was often characterized by hard labour and violence. Karen Sánchez-Eppler notes that historians of enslaved childhood have tended to accept a definition of childhood "as a protected time of nurture and free play" - the polar opposite of enslavement. ${ }^{14}$ While some enslaved children remained able to have "protected time," this was rarely the case for free black children who lived among enslaved communities or within white households. This article concurs with the view that childhood is a "very specific cultural phenomenon," with modern conceptions of childhood evolving from Enlightenment ideas. Childhood also has biological and legal understandings that are of relevance to both enslaved and free black children. ${ }^{\text {s }}$ So while the biological context of childhood relates to issues of physical and psychological dependency, legal conceptions of childhood in the antebellum South also held resonance for free black children. As will be shown, although they (along with enslaved people) were excluded from legal citizenship until after the Civil War, many

${ }^{13}$ Marisa Fuentes probes archival silences in Dispossessed Lives: Enslaved Women, Violence and the Archive (Philadelphia: University of Pennsylvania Press, 2016), especially the introduction. See also Stephanie Camp, Closer to Freedom: Enslaved Women and Everyday Resistance in the Plantation South (Chapel Hill and London: University of North Carolina Press, 2004), 95; Sarah Haley, No Mercy Here: Gender, Punishment, and the Making of Jim Crow Modernity (Chapel Hill: University of North Carolina Press, 2016), 62-63. Erica Armstrong Dunbar eloquently and adeptly pieces together the live of Ona Judge in Never Caught: The Washingtons' Relentless Pursuit of their Runaway Slave, Ona Judge (New York: Simon and Shuster, 2017).

${ }^{14}$ Karen Sánchez-Eppler, "Remember, Dear, When the Yankees Came through Here, I Was Only Ten Years Old": Valuing the Enslaved Child of the WPA Narratives," in Anna Mae Duane, ed., Child Slavery before and after Emancipation (New York: Cambridge University Press, 2017), 27-49, 35.

is Ibid. Anna Mae Duane argues that conceptualizations of childhood evolved from Enlightenment ideas about power, self-government and consent that "rendered children incapable of participating in the contractual obligations that would come to occupy center stage in liberal democratic thought and would emerge as a key rubric for distinguishing between slavery and freedom." Duane, 6 . 
southern state legislators considered and debated various laws about free children of colour at a more localized level.

A rhetoric of paternalism provided this means by which slaveholders and lawmakers infantilized their chattel and framed their treatment of enslaved people and free people of colour within discourses of "care and education" that were in the alleged "best interests" of black people they believed to be biologically and culturally inferior. Indeed, by framing their use of free black children's labour in terms of "benevolent help," enslavers provided ammunition to the pro-slavery ideology of paternalism that enslavement was in the best interests of all black people. George Fitzhugh, for example, believed that the very notion of "a free negro" was "an absurdity" and argued for the desirability of their enslavement on the grounds of "humanity, self-interest, and consistency." ${ }^{\text {} 6}$ As pointed out by Rebecca de Schweinitz, specific ideas about childhood and dependency also influenced pro-slavery advocates, who drew a parallel between the dependence of children on parents and of enslaved people on slaveholders. ${ }^{17}$

Perhaps because of the methodological challenges inherent in exploring the lives of free black children, most analyses of black childhood in the nineteenthcentury US have focussed on the more numerically significant experiences of enslaved children. ${ }^{18}$ The two and a half thousand interviews conducted by the Works Progress Administration in the Depression of the 1930s, for example, contain testimony from former slaves (and a small number of free

${ }^{16}$ See George Fitzhugh, "What Shall Be Done with the Free Negroes? Essays Written for the Fredericksburg Recorder," Fredericksburg Recorder, i 85 I, 6, quoted in Michael P. Johnson and James L. Roark, "Strategies of Survival: Free Negro Families and the Problem of Slavery," in Carol Bleser, ed., In Joy and in Sorrow: Women, Family and Marriage in the Victorian South (New York: Oxford University Press, I991), 88-102, 90 n. 10. Fitzhugh, Sociology for the South: or, The Failure of Free Society (Richmond: A. Morris, I 854), 264.

17 Rebecca de Schweinitz, "WWaked Up to Feel': Defining Childhood, Debating Slavery in Antebellum America," in James Marten, ed., Children and Youth during the Civil War Era (New York and London: New York University Press, 2012), 13-28, esp. 22. Of course, the emergence of modern forms of sentimental childhood in the nineteenth century also provided an easy way for abolitionists to critique slavery through emotional appeals to the heart via the separation of parents and "innocent" children in sentimental literature. See, for example, Robin Bernstein, Racial Innocence: Performing American Childhood from Slavery to Civil Rights (New York and London: New York University Press, 20I I), 4-5.

${ }^{18}$ For example, Steven Mintz's broad survey of American childhood considers only enslaved children in the antebellum era. See his Huck's Raft: A History of American Childhood (Cambridge, MA and London: Belknap Press, 2004), 94-1 17. Peter Stearns argues that childhood under slavery displayed some standard characteristics of lower-class childhood, for example hard work, but also some specific difficulties, for example the threat of sale and separation. See his Childhood in World History (New York and Abingdon: Routledge, 20I I; first published 2006), 86. 
blacks) who were young at the time of emancipation. ${ }^{19}$ They experienced slavery from the perspective of the young and have been used extensively in recent works about enslaved childhood and youth, including the work of Wilma King and Marie Jenkins Schwartz. King argues "childhood" (in terms of modern understandings of the concept which stress nurture and free time) did not exist under slavery, but she acknowledges that enslaved parents sometimes were able to make enslaved childhood "a special time." 20 Schwartz notes that enslaved childhood was distinct from adulthood, but was "bounded by the constraints of slavery." ${ }^{21}$ Rachael Pasierowska has recently considered the point at which enslaved children recognized and internalized their bondage. ${ }^{22}$

All these works focus on enslaved, rather than free, black children, but the lives of nominally free youngsters who lived on plantations and farms among enslaved communities were largely shaped by the same forces as those enslaved. Slaveholders strove to eke out maximum profits from all, whether young or old, male or female, healthy or sick, pregnant or not. Formerly enslaved WPA respondents often recalled very young and elderly people being required to work in so-called "trash gangs" - carrying out small tasks in the plantation home, picking up litter, washing clothes, preparing food, toting water or caring for even younger children. ${ }^{23}$ By the age of five or six, most enslaved children moved from being regarded almost as "pets" or "playmates" for young white children into being small labourers in their own right, as Wilma Dunaway has argued. ${ }^{24}$ By adolescence, most enslavers considered children to be "prime" hands and the majority began to labour in the fields, with a smaller proportion working in plantation homes as domestics. ${ }^{25}$ Evidence

19 See John Blassingame, ed., Slave Testimony: Two Centuries of Letters, Speeches, Interviews, and Autobiographies (Baton Rouge and London: Louisiana State University Press, 1977), 1.

${ }^{20}$ Wilma King, Stolen Childhood: Slave Youth in Nineteenth-Century America (Bloomington and Indianapolis: Indiana University Press, I 995), xxi, I.

${ }^{21}$ Marie Jenkins Schwartz, Born in Bondage: Growing Up Enslaved in the Antebellum South (Cambridge, MA and London: Harvard University Press, 2000), I 4.

${ }^{22}$ Rachael Pasierowska, "Up from Childhood: When African American Enslaved Children Learned of Their Servile Status," Slavery and Abolition, 27, I (March 2016), 94-1 I6.

${ }^{23}$ Deborah G. White has shown how these gangs, while ultimately based upon labour, also fostered female camaraderie, and opportunities for elderly or pregnant women to teach younger girls how to negotiate their enslavement. See her Ar'n't I a Woman? Female Slaves in the Plantation South (New York: W. W. Norton, 1985), chapters 3 and 4.

${ }^{24}$ Wilma Dunaway, The African-American Family in Slavery and Emancipation (Cambridge: Cambridge University Press, 2003), 72-73.

${ }^{25}$ Walter Johnson notes that until the age of around ten, children were regarded as only "quarter hands," compared to nursing mothers designated as "half hands," and before that a child's value was purely speculative. See his River of Dark Dreams: Slavery and Empire in the Cotton Kingdom (Cambridge, MA and London: Belknap, 2013), 197. For Gwyn Campbell, physical maturation (maximum height for boys and menstruation for 
suggests that these patterns also held true for free people of colour who lived among the enslaved. However, rather than having one "point of recognition" of their status (as enslaved children did), it will be shown that free black children were often rather confused about their legal status because their lives were so similar to those of slave children. These sentiments hence reflect the wider ambiguity along the divide between slavery and freedom even as enslavers increasingly attempted to create a harsh delineation between these two groups by late antebellum times.

Over the course of the antebellum era pro-slavery ideology grew more entrenched and state legislatures increasingly legislated against free blacks, with flurries of new restrictive legislation often following white panics such as those created by the Denmark Vesey conspiracy in 1822 and the Nat Turner insurrection in $183 \mathrm{I}$. So while legislative action ebbed and flowed over time to some extent, legal debates and the subsequent laws imposed brought further restrictions and created an ever more hostile environment for free people of colour over the course of the antebellum era. Moreover, the Dred Scott Supreme Court decision of I 857 that "once free no longer meant always free" excluded Scott from citizenship because of his race, and, in denying free blacks' rights, the case placed the weight of law behind proslavery ideology. ${ }^{26}$ White southerners ultimately perceived free people of colour to be a problematic and undesirable group who might entice the enslaved into revolt. Their very existence upset developing ideologies of racial difference that deemed blacks innately inferior to whites.

So despite free people of colour's valuable economic input, southern legislatures, via local laws, statutes and ordinances, increasingly attempted to prevent the migration of free blacks into states; restricted emancipations; set up complicated systems of registration, taxation and guardianship; and attempted to send some free blacks "back" to Africa via colonization initiatives, even though the great majority had been born on American soil. ${ }^{27}$ By

girls) often signalled the end of childhood and a move into adulthood. Campbell thus claims that until the age of 12 slaveholders normally considered enslaved people "children" then from 12 to 15 or 18 they were defined as "youths." See Gwyn Campbell, "Children and Slavery in the New World: A Review," Slavery and Abolition, 27, 2 (2006), 26I-85, esp. $26 \mathrm{I}-62$.

${ }^{26}$ See Jones, Birthright Citizens, I 3 I-36. Drew Gilpin Faust, Ideology of Slavery, 5-6, argues that from the 1830 s onwards, pro-slavery ideology grew less concerned about justifying slavery itself, and more interested in arguing why it was right. Barbara Fields, Slavery and Freedom on the Middle Ground: Maryland during the Nineteenth Century (New Haven and London: Yale University Press, 1985), 79, also stresses movement towards "harsher and more punitive legislation" directed against free people of colour in Maryland.

27 West, Family or Freedom, 22-23. For more on African American efforts to be granted birthright citizenship see Jones. 
the i 85 os states debated (and some even legislated) either expelling or enslaving free southern blacks, and these laws provide insights into contemporary attitudes towards childhood and dependency via the age at which state legislators believed free black individuals might "consent" to become enslaved.

For example, from i 856 onwards Virginia proudly proclaimed that any free man of colour over the age of twenty-one, and free black women over the age of eighteen, could "choose a master" via legislative or court petition. ${ }^{28}$ Gender additionally influenced ideas of consent, with women assumed to have reached an ability to agree prior to men. Other states followed suit, some of which permitted any free women of colour requesting enslavement to take their children into bondage with them. In Louisiana, from i 859 onwards, any child under ten years old automatically became enslaved if their mother did. Florida and Texas decreed in 1858 that anyone over the age of fourteen could "select" enslavement, while mothers could "choose" whether any children under this age might become a slave. Texas also legislated for the enslavement of free black orphans under fourteen, with the explicit support of free black adults. Virginia and Tennessee, conversely, expressly forbade the enslavement of people under the age of eighteen, allegedly in a nod to humanitarian concerns but also probably due to the fact that newly enslaved adults were more desirable economically than their children. ${ }^{29}$ Adolescence hence represented the point at which most legislators assumed people could "consent" to slavery, and this varied by gender, with girls tending to mature earlier than boys, although, rather like childhood itself, the understandings and conceptualizations of adolescence varied widely among southern lawmakers. ${ }^{\circ}$ Ultimately, though, despite some public rhetoric around ideas of "consent," legislators'

${ }^{28}$ A further six states then enacted similar legislation enabling "voluntary enslavement," while South Carolina and Georgia permitted it through special legislative act. Essentially, all states were moving in a similar direction towards a situation where to be white meant to be free, to be black meant to be enslaved. West, $45-48$. Southern states also debated the enforced expulsion of free blacks. In February i 859 Arkansas outlawed all emancipations and also famously declared "no free negro or mulatto to reside in the State after ist January I 860." See An Act to Remove the Free Negroes and Mulattoes from This State (number 151), approved I2 Feb. 1859. Acts Passed at the Twelfth Session of the General Assembly of the State of Arkansas, 1858-1859, Acts of Arkansas, pp. 175-78, Arkansas History Commission and State Archives, Little Rock (AHCSA).

29 West, $45-48$.

30 The ability to consent is a crucial component in defining modern childhood. See Anna Mae Duane, Suffering Childhood in Early America: Violence, Race and the Making of the Child Victim (Athens: University of Georgia Press, 2010), 6. Holly Brewer, By Birth or Consent: Children, Law, and the Anglo-American Revolution in Authority (Chapel Hill: University of North Carolina Press, 2007), 4, claims that children lost their right to consent during American revolutionary reforms based on John Locke's ideas about an "age of reason." 
desire to bring young free black people (especially women with children or future reproductive value) into the slave regime assumed priority in lawmaking.

Following these legal debates and rulings, a tiny minority of southern free people of colour sought recourse to the law in an attempt to move from freedom to bondage. Their often poignant petitions for so-called "voluntary enslavement" illustrate the sheer distress and poverty of antebellum free blacks who fought to "remain still" with their families, in their homes, enmeshed in broader communities, and they prioritized their immediate affective ties over and above their legal status, and sometimes even their freedom. ${ }^{31}$ But, importantly, it was not necessary for free people of colour to seek recourse to the law in an attempt to remain with their families or to avoid impoverishment. Instead, some free blacks moved into forms of temporary apprenticeship or indentured servitude sanctioned by individual state laws. However, the lived experiences of those who resided among enslaved communities on plantations and farms have been overlooked, in part because the informal nature of any arrangements they had with enslavers means that there is a paucity of written documentation about them. These people appear to have been treated as though enslaved. Hence the WPA testimony from free people of colour considered here is extremely valuable in considering those on the interstices between slavery and freedom who lived in forms of informal enslavement. Moreover, in their desire to remain with beloved kin, free blacks' prioritization of affective ties above all else displays significant parallels with those who petitioned for legal enslavement.

White families in the antebellum South sometimes legally apprenticed free black children, a system "rooted in Old World poor laws and customs" that had been transported to colonial America. ${ }^{32}$ Most apprenticeship occurred

${ }^{31}$ Enslavement petitioners are numerically extremely small. The author found just 143 enslavement petitions across the southern states from the revolutionary era through the Civil War (detailed in West, Family or Freedom), while Ted Maris-Wolf's more recent and geographically contained study of self-enslavement found I 10 enslavement petitioners in antebellum Virginia alone. See Ted Maris-Wolf, Family Bonds: Free Blacks and Re-enslavement Law in Antebellum Virginia (Chapel Hill: University of North Carolina Press, 2015).

${ }^{2}$ See Ruth Herndon and John E. Murray, "Overviews," in Herndon and Murray, eds., Children Bound to Labor: The Pauper Apprentice System in Early America (Ithaca: Cornell University Press, 2009), I-2, 2. Barry Levy discovered that free people of colour in colonial Boston commonly had to bind out their own children, as did some poorer white families. Enslaved children, too, were frequently gifted away via advertisements, "like excess kittens." See Barry Levy, Town Born: The Political Economy of New England from Its Founding to the Revolution (Philadelphia: University of Pennsylvania Press, 2009), 40-4I. Conversely, in the antebellum South, enslavers commonly gifted away young people to family members rather than via advertisements. Sarah Winter, "The Slave Child as 'Gift': Involutions of Proprietary and Familial Relations in the Slaveholding Household before Emancipation," in Duane, Child Slavery, 50-74.This 
because of poverty and historians of antebellum southern apprenticeship have tended to focus upon this formal - rather than any informal - binding of free black children. Ira Berlin believed the apprenticeship of free black southern children failed to embody the principle of apprenticeship as a form of education and training by which people could learn to support themselves and improve their life chances. Instead it became a highly exploitative system of labour. ${ }^{33}$ In her longer-run analysis of the practice in North Carolina, Karin Zipf claims that, far from "training children for a craft," apprenticeship served as a form of white patriarchal control that denied women and African American men the right to guardianship of their children. ${ }^{34}$ Holly Brewer also explores the negative dimensions of child apprenticeship. She argues that overseers of the poor were much more likely to bind out free black children in Virginia than they were those who were white. Poverty and race therefore negated parental custody, as free blacks' lack of legal citizenship rendered them more powerless than white citizens when it came to apprenticing children. Brewer argues the practice of formal legal child apprenticeship overall was more common in the northern US after the Revolution because gradual emancipation sometimes required that black children serve a period of apprenticeship before acquiring their freedom. ${ }^{35}$ But the continuation of slavery in the South rendered white citizens less desirous of temporary systems of indenture. Even more formal systems of apprenticeship for black children in the South were more fluid and flexible than in the North, which obviously worked to the advantage of white southerners rather than

practice hence enabled enslavers to congratulate themselves on keeping slavery "within the family" in line with the ideology and rhetoric of paternalism.

${ }^{33}$ Ira Berlin, Slaves without Masters: The Free Negro in the Antebellum South (New York: Pantheon, 1974), 223-25, and 236-37.

${ }^{34}$ Karin Zipf, Labor of Innocents: Forced Apprenticeship in North Carolina, I715-1919 (Baton Rouge: Louisiana State University Press, 2005), 7.

${ }^{35}$ Holly Brewer, "Apprenticeship Policy in Virginia: From Patriarchal to Republican Policies of Social Welfare," in Herndon and Murray, Children Bound to Labor, 1 83-97, esp. 194. See also Brewer, By Birth or Consent, 264. Likewise, Barbara Bennett Woodhouse claims that racism denied apprenticed free black children some of the protections granted to white bound children. See Barbara Bennett, Hidden in Plain Sight: The Tragedy of Children's Rights from Ben Franklin to Lionel Tate (Princeton, NJ: Princeton University Press, 2008), 66. Jessica Millward's study of enslaved and free black women in Maryland reveals how women manumitted in the early decades of the nineteenth century faced legal moves to bind their children into enslavement and apprenticeships. See Jessica Millward, Finding Charity's Folk: Enslaved and Free Black Women in Maryland (Athens and London: University of Georgia Press, 2015), 55. Jennifer Hull Dorsey also suggests, within Maryland, a process of racialization in the apprenticeship system over the course of the nineteenth century. See Jennifer Hull Dorsey, Hirelings: African American Workers and Free Labor in Early Maryland (Ithaca, NY: Cornell University Press, 201 I ), I 31. 
of the young free blacks themselves. ${ }^{36}$ The practice also lingered well into the postbellum era, as white southerners fought to maintain and reshape their systems of control over people of colour. ${ }^{37}$

WPA evidence suggests that free black children living within white households and plantations (sometimes with their parents and sometimes without) did not learn valuable manual skills or trades, and lived in a very similar way to rank-and-file enslaved people. Furthermore, although free black children might be spared the trauma of sale or separation, slaveholders had no vested interest in the potential "future capital" of free black children as labourers (and for girls also as reproducers) because they did not own them. So enslavers probably failed to grant free black children "protected" time, being less interested in their long-term development and health, in contrast to their enslaved children. Instead, they would have worked free children in positions of informal slavery incredibly hard despite their alleged free status, especially when these children's parents had no power to influence the treatment of their offspring.

The experiences of the Lundy children of Mississippi supports these assertions. In I 854 the Pike County Board of Police unusually authorized a public auction to hire out a number of free people of colour in the county who all bore the surname Lundy. The policy was designed to raise a fund of some six thousand dollars to ship the Lundys to Liberia and provide for them for one year thereafter-so removing the perceived "problem" of these free blacks in Mississippi-but it is unknown whether the Lundys themselves were instrumental in initiating this request. ${ }^{38}$ While state-level fund-raising

${ }^{36}$ Conversely, James D. Watkinson argues that young free blacks in Lancaster County, Virginia often did well out of their apprenticeships, learning valuable skilled trades such as carpentry, shoemaking, sewing and weaving. See James D. Watkinson, "“Fit Objects of Charity': Community, Faith, Race and Welfare in Antebellum Lancaster County, Virginia, I 817-1860," Journal of the Early Republic, 2 I, I (Spring 200 I), 41-70. Likewise William Ransom Hogan and Edwin Adams Davis argue that William Johnson, a free black barber and diarist in Natchez, treated his young apprentices well, whether free blacks or enslaved. They learned valuable skills, obtained a rudimentary education, and were also sometimes fed and clothed. See William Ransom Hogan and Edwin Adams Davis, William Johnson's Natchez: The Ante-bellum Diary of a Free Negro (Baton Rouge: Louisiana State University Press, 1993; first published 1951), 27-28. The provision of food and clothing was more common for child apprenticeships than for adults across time and space. See Christopher Tomlins, Freedom Bound: Law, Labor and Civic Identity in Colonizing English America, 1580-1865 (New York and Cambridge: Cambridge University Press, 2010), 242-43.

37 Fields, Slavery and Freedom on the Middle Ground, I 54; Zipf, 66-67.

${ }^{38}$ An Act to Empower the Board of Police of Pike County to Remove the Lundy Free Negroes Living in Said County to Liberia, approved 1o Feb. 1854, Laws of the State of Mississippi, Passed at a Regular Session of the Mississippi Legislature Held in the City of Jackson (Jackson: E. Barksdale, State Printer, I 852), 287-88, Mississippi Department of Archives and History, Jackson (MDAH). Black attitudes to colonization varied; for an overview 
for colonization initiatives through the hiring out of free blacks was rare, southern states as a whole tended to perceive colonization in favourable terms. For example, the Virginia legislature authorized an annual fund in I 850 to provide for the removal of free people of colour to Liberia. ${ }^{39}$ But most legislative petitions concerning colonization tended to be submitted by white citizens requesting that free blacks be removed on the ground that their very existence in the US was troublesome within a biracial slave regime. ${ }^{40}$

The I 850 Census lists twenty-six black or "mulatto" people with the surname Lundy in Pike County, spread across various police districts. Fifteen Lundys resided in one large multigenerational farming household - a common family formation for people living in poverty across time and space because extended families provide additional labour for financial support and women can share childcare responsibilities. ${ }^{41}$ However, the Census also reveals a number of other free black Lundy children spread throughout eight white-headed households, of whom the eldest, John, was fifteen, while the youngest, Celia and Bob, were just six years old, as was another probable Lundy child mis-transcribed as "Wesley Sundy." ${ }_{22}$ The majority of these children lived with white families, three of which bore the family name Quin, so the children might have lived close enough to each other to allow visits. ${ }^{43}$ Most of the white families were listed as "farmers," sometimes with additional young white adults working as farmhands or overseers, presumably lodgers. John Lundy, aged fifteen, was described as a farmhand, labouring for the Stallin family of farmers. ${ }^{4}$ Conversely, fourteenyear-old Ann Lundy lived within a tavern owned by the white Williams

see David Brian Davis, Challenging the Boundaries of Slavery (Cambridge, MA: Harvard University Press, 2003), 62-74.

39 An Act for Making Appropriations for the Removal of Free Persons of Color, and for Other Purposes, Acts of the General Assembly of Virginia Passed at the Extra and Regular Sessions, I 849 and I 850 (Richmond: William F. Ritchie, I 850 ), 7, Library of Virginia, Richmond. See also William Link, Roots of Secession: Slavery and Politics in Antebellum Virginia (Chapel Hill: University of North Carolina Press, 2003), i 55-57.

${ }^{40}$ For more on these cases see West, 66-67.

${ }^{41}$ The 1850 Federal Census, Police District 2, Pike, Mississippi, Roll 380, p. ${ }_{7} \mathrm{~B}$.

${ }^{42}$ The 1850 Federal Census, Police District I, Pike, Mississippi, Roll 380, p. I9A (John); Police District 5, Pike, Mississippi, Roll 380, p. 7 B (Celia); Police District 2, Pike, Mississippi, Roll 380, p. 9 A (Bob); Police District 2, Pike, Mississippi, Roll 380, p. 4A (Wesley).

${ }^{43}$ For example, Goober Lundy (age seven) and Bob Lundy (age six), lived in Quin households adjacent to each other in the 1850 Federal Census. See Police District 2, Pike, Mississippi, Roll 380, p. 9A. Celia Lundy, also age six and detailed above, also lived within a Quin household.

${ }^{44}$ John Lundy is detailed above. Sarah Lundy (age I I) lived with a white lawyer and his family (John Lamkin) along with another free girl of colour aged I 2 named Laticia Parsons. Police District I, Pike, Mississippi, Roll 380, p. I B; Cindarilla and Jane Lundy (age I I and nine) 
family, alongside a range of single adult white men. At her age, Ann was most likely employed to perform domestic work about the tavern. ${ }^{45}$ These Lundy children were hired out to white people, either alone or in pairs, probably either to earn additional money for the colonization fund or to spare the extended Lundy household from the financial burden of raising them. They probably performed domestic chores, performed field labour on the farms or on the plantations where the white overseers they lived with also worked, or helped care for white or enslaved infants.

Moreover, because enslaved children held additional value to slaveholders as goods or commodities to be bought and sold as well as for the labour they performed, their time might well have been more "protected" than that of free black children in order to maximize their potential future value. In contrast, de facto slaves - free black children - could not be sold or gifted away so enslavers probably eked out maximum labour from them instead. ${ }^{46}$ The experience of the Lundy children invokes the concepts of guardianship and paternalism that Anna Mae Duane notes "undergird slavery," but it additionally speaks to a capitalistic regime where profit reigned supreme. ${ }^{47}$ The labour of these children would either have been very similar to that performed by enslaved children, or, tragically, it could have been even more arduous because the white families with whom they resided had no long-term interest in preserving their economic value because they could not be sold as chattel. So any notion that the Lundy children were "free" people of colour is rendered rather

lived with a merchant named George Nicholson and his family, along with a clerk named Franklin Quin (age 20). Police District I, Pike, Mississippi, Roll 380, p. 2A.

${ }^{45}$ Police District I, Pike, Mississippi, Roll 380 , p. I A. Because of Anne's age she was at risk of sexual assault from the single white men living in the tavern, although married white men have also sexually abused black women throughout American history.

46 The value of enslaved children is discussed in Sánchez-Eppler, "Remember, Dear, When the Yankees Came through Here," 42. See also Daina Ramey Berry, The Price for Their Pound of Flesh: The Value of the Enslaved, from Womb to Grave, in the Building of the Nation (Boston: Beacon Press, 2017).

47 Anna Mae Duane, "Introduction," in Duane, Child Slavery, I-22, 4. A lot of recent literature has focussed on the importance of slavery to the development of US capitalism, including Edward E. Baptist, The Half Has Never Been Told: Slavery and the Making of American Capitalism (New York: Basic Books, 20I4). But this work has been contested in terms of the originality of the claims made and for the authors' relative neglect of role played by women in fostering economic development via their reproductive abilities. See, for example, John E. Murray, Alan L. Olmstead, Jonathan B. Pritchett and Peter L. Rousseau, "Roundtable of Reviews for The Half Has Never Been Told," Journal of Economic History, 75, 3 (Sept. 2015), 919-31; Matthew Pratt Guterl, "Slavery and Capitalism: A Review Essay," Journal of Southern History, 8 I, 2 (May 2015), 404-20; Scott Reynolds Nelson, "Who Put Their Capitalism in My Slavery," Journal of the Civil War Era, 5, 2 (June 2015), 289-3 10, Amy Dru Stanley, "Histories of Capitalism and Sex Difference," Journal of the Early Republic, 36, 2 (Summer 2016), 343-50. 
meaningless by the reality of their day-to-day existence. Racial slavery led to many different manifestations of exploitation, affecting free blacks as well as those legally enslaved.

The formations of the white families with whom the Lundy children resided also reveal that all bar one of the households (that of Ann Lundy) held a number of enslaved people in addition to the "free" black Lundy children. For example, fifteen-year-old John Lundy lived with the Stallins, who owned five enslaved people. Sarah Lundy resided in the home of the Lamkins along with their forty-two slaves. ${ }^{8}$ While surviving written testimony is lacking, it can be hypothesized that in their hiring of these free black children, the white families regarded the Lundy children as slaves in all but name: children who resided within broader enslaved communities despite their free legal status. Additionally, these children might not even have known they were free, and simply assumed they, like others around them, belonged to others. Nor do the Lundy children appear to have lived with their free black mothers in their white households, women who could have tried to prevent their exploitation and assert their free status. The children might have felt isolated and lonely, bereft of parental love and affection, though the voices of these young "slaves in all but name" are sadly absent from the historical record. Attempts to raise enough money to ship the Lundys to Liberia appear to have failed. In the I 860 Census for Pike County, at least half of these young free people of colour still lived within the same white households as they did in I 850 , while the elder ones appear to be living in their own households. ${ }^{49}$ The story of the Lundy children is one of continuities rather than changes within wider forms of de facto slavery that exploited the poor and powerless, and flexible and informal systems of hiring and apprenticeship for free people of colour. ${ }^{\circ}$

While the Lundy children left no testimony of their own, evidence about informal modes of enslavement that sometimes parallel the experiences of the Lundys can be found in the testimony of WPA respondents, some of whom recalled free people of colour - including children - living, loving and working among broader enslaved communities. White residents of Pike County, Mississippi hired the Lundy children to raise money for a

${ }^{48}$ James Stallin appears as James Stalings on the slave schedules for 1850 . See "Slave Inhabitants in the County of Pike, Enumerated on the 30th August I850," The National Archive in Washington, DC, NARA Microform Publication, M432, Title: Seventh Census of the United States, i 850 , Record Group: Records of the Bureau of the Census, Record Group Number 29.

49 The Lundys can be seen on the I 860 Census for Pike County, assessible at www.ancestry. $\mathrm{com} / \mathrm{search} /$ collections $/ 7667 /$ ?name $=\_$lundy\&count $=50 \&$ name_x $=$ I_I \& residence $=\_p i k e-$ mississippi-usa_2363.

so The experiences of the Lundy children have been considered more briefly in West, Family or Freedom, 68-70. 
colonization initiative that ultimately failed. However, the WPA evidence explored here from across the antebellum South suggests other important reasons about how and why free people of colour ended up living among the enslaved from the perspectives of those involved rather than those of whites. The WPA interviewees' explanations about free blacks' lives display certain similarities with the "voluntary" enslavement petitions submitted by a small minority of free people of colour in the antebellum era; some respondents wanted to retain their affective ties to family members, and feared being parted from them, especially in cases of enslavers' westward migration. Other free black children resulted from interracial sexual contact between white women and black men and they ended up being separated from their biological mothers and being raised within enslaved communities. Finally, poverty and deprivation meant that some free black people had no choice but to live among the enslaved and labour as though they were held in bondage.

WPA interviewees often indicated with a sense of pride that their parents had been free rather than enslaved. In particular, free black fathers married or in intimate relationships with enslaved women sometimes worked alongside slaves on farms and plantations, their lives differing very little from those enslaved on a day-to-day level despite their legal status as free. ${ }^{51}$ In these cases, unlike the Lundys, the free black children involved lived with at least one of their parents. For example, Millie Simkins said her father was free, but her mother enslaved. Her father worked for her mother's enslaver as a stable boy, living among this wider enslaved community. However, he later "ran away" and never returned although she elaborated no further about why he did so.52 Significantly, Simkins used the language of slavery when describing her everyday life and her father must certainly have been extremely troubled to leave his home and his family, although his motivations are hidden from history. Nor do we know whether Simkins's father had entered into any legal agreement with her enslaver, obliging him to remain on his slaveholding. But, in many ways, the experiences of Simkins's father display parallels with those of enslaved men who escaped bondage, with men being more likely

${ }^{11}$ Although not legal under US law, enslaved people did enter wedlock having undergone wedding ceremonies. Their marriages were hence recognized by wider society. See Emily West, Chains of Love: Slave Couples in Antebellum South Carolina (Urbana and Chicago: University of Illinois Press, 2004), chapter I. Likewise, the marriages between slaves and free people of colour were also recognized by wider society but not by the law. See Tera W. Hunter, Bound in Wedlock: Slavery and Free Black Marriage in the Nineteenth Century (Cambridge, MA and London: Harvard University Press, 2017), chapters I-3. This article uses terms such as "marriage" "wedlock" and "intimate relationships" interchangeably when referring to relationships between the enslaved and free people of colour in order to signify respect for the sanctity of their relationships.

52 Millie Simkins, Slave Narrative Project, Vol. I 5, Tennessee (Batson-Young), 69. 
than women to flee this form of oppression. ${ }^{53}$ Moreover, free black men who had children with enslaved women had to bear the knowledge that any child of theirs would automatically be enslaved to the enslavers of their spouses. This gave slaveholders a very real financial incentive when it came to allowing free men of colour to live among their enslaved people.

Anna Baker from Mississippi said that her grandmother's master had invited Anna's grandfather, a "full-blooded Injun," she claimed, rather than a free black man, to work alongside his slaves: "When he took up wid my grandmammy de white man what owned her tells him iffen he want to stay wid her dat he's give him a home iffen he's work for him lak de [slaves] on de place." This clever bribe effectively permitted a loving couple to live together only if Baker's grandfather was prepared to work for free in return for creating a marital home on the plantation, and while we do not know when this arrangement took place, it can additionally be assumed that if Anna's grandmother had been of childbearing age her enslaver would have hoped that her relationship would result in children that belonged to him. The agreement appears to have worked only until an overseer tried to beat Baker's grandfather - after this conflict he left the plantation and his quasienslavement-but also his family. ${ }^{54}$ As was the case with Simkins's father also, free men involved in intimate relationships with enslaved women sometimes had incredibly difficult choices to make between their freedom and their families. Flexible and adaptable labour systems and non-pecuniary benefits sometimes advantaged families that crossed the boundary between enslaved and free. In these two case the couples involved no doubt appreciated the ability to share a home and be together every day. These practical and emotional advantages outweighed any "stigma" the men might have received for working alongside the enslaved despite the fact that these men's children would be born into bondage. But slaveholders and other white people in positions of authority such as overseers seem not to have recognized that legal status as a mark of difference is a regime built upon the divisions created by race, hence the overseer's beating of Baker's grandfather and his subsequent flight.

William Sherman's father, also named William Sherman, had been a skilled blacksmith who managed to buy his freedom through hiring himself out to local plantation owners and saving the money he earned from this work. His former enslaver, John Jones, however, retained a degree of control over

53 For more on the gender dimension of runaway slaves see John Hope Franklin and Loren Schweninger, Runaway Slaves: Rebels on the Plantation (New York and Oxford: Oxford University Press, 1999), esp. chapter 9.

${ }^{54}$ Anna Baker in George P. Rawick, ed., The American Slave: A Composite Autobiography, Supplement Series I, Volume VIII, Mississippi Narratives Part 2, 99. 
Sherman senior by serving as his legal guardian. This meant that Sherman retained close ties to his former slaveholding, especially since he was married to an enslaved woman owned by Jones named Anna Georgia, the mother of Sherman junior. Poignantly, Sherman said his father was unable to save up enough money before his death to purchase his enslaved wife and child.55 Samuel Smalls's father, more unusually, entered a period of indentured labour for the enslaved woman he loved, though it is unknown whether this arrangement was formalized via documentation. Smalls said his father, Cato Smith, travelled to Florida from the northern US. His parents had been enslaved in Connecticut prior to their emancipation there. A carpenter and builder, Smith enjoyed travelling, and spent some time labouring in the southern states, including some time working as a black overseer in Suwannee County, where he fell in love with a woman on neighbouring plantation. Her enslaver told Smith he would have to work unpaid on the plantation for seven years in order to live with her as his wife, and Smith then obliged. The WPA interviewer remarked himself that Smith was "practically" enslaved, indicating his understanding of slavery as a spectrum rather than as a binary between bondage and freedom. ${ }^{6}$ Similarly, Erica Armstrong Dunbar describes a northern free person of colour - in this case a woman named Margaret Thomas-who wed William Lee, George Washington's enslaved valet. Dunbar writes that Thomas made "an odd and dangerous request to move south with her beloved." Washington granted this request, meaning that the couple could live together on his Mount Vernon estate. However, no evidence survives that indicates whether Thomas actually moved to Virginia or not. Dunbar speculates that she might have died, left the marriage, or more probably had doubts about exchanging her life in Philadelphia for one in Virginia, and "placing her free status in serious jeopardy." Unlike the experiences of some of the WPA respondents explored here, then, in this case love may not have been "a strong enough pull to compete with freedom." 57

Other free black husbands only visited the homes of their enslaved wives and children and did not permanently reside with them. Some men might understandably have feared becoming "slaves in all but name" like some of

ss William Sherman, Slave Narrative Project, Vol. 3, Florida (Anderson-Wilson, with combined interviews of others), 289-90. Larry Koger has written about free people of colour who purchased their loved ones, describing the practice as "nominal slavery." See Larry Koger, Black Slaveowners: Free Black Masters in South Carolina, 1790-1860 (London: McFarland, 1985), 69.

${ }_{56}$ Samuel Smalls, Slave Narrative Project, Vol. 3, Florida (Anderson-Wilson, with combined interviews of others) $303-4$. On the evolution of the overseer system, including the use of free black and enslaved overseers, see Laura Sandy, Overseers of Early American Slavery: Supervisors, Enslaved Labourers, and the Plantation Enterprise (New York: Routledge, 2020), esp. 26-27, 49, 225-27.

${ }^{57}$ Dunbar, Never Caught, 26-27. 
the men considered here, and may have chosen to reject any offers or bribes made by their wives' enslavers. Alternatively, slave-owners might not have welcomed free men of colour into their homes, farms and plantations. In these cases, free black men had to simply accept the rules and regulations about visitation rights imposed by their wives' enslavers, unless they were prepared to risk illicit visits. Held in bondage in Kentucky, Mrs. William Perry's free black father visited the family cabin on a regular basis, in a similar way to enslaved men in cross-plantation marriages, most of whom saw their wives only at weekends. ${ }^{58}$ However, Perry elaborated no more about whether the decision not to live with his family was her father's choice, or that of her mother's enslaver.

Other interviewees spoke more explicitly about slaveholders' visitation rules for free people of colour. Jerry Moore recalled how his father, having bought his freedom from his enslaver in Alabama, was subsequently assigned a guardian and "wasn't allowed" to live among slaves. 59 Freeborn William Scott from Raleigh, North Carolina said his free black parents were not allowed to go to plantations "much," and Elizabeth Sparks, enslaved in Virginia, recalled how free people of colour could only visit plantations "if yer was their folks." This suggests, again, that free blacks and the enslaved were enmeshed together within wider families and communities in the plantation South. ${ }^{60}$ In Texas, Mary Reynolds's free black father attempted to negotiate with his wife's enslaver to buy her from him. But Dr. Kilpatrick was well aware of this woman's value to him both as a worker and as a reproducer. "Dr Kilpatrick was never one to sell any but the old [slaves] who was past workin' in the fields and past their breedin' times," Mary recalled, conveying a keen awareness of enslaved people's fluctuating values as chattel over their life cycles. So "my paw married my maw and works in the field the same as any other." They had six daughters, including Mary, and her father chose to live in quasi-slavery surrounded by his family members rather than alone as a free man. ${ }^{61}$

Dr. Kilpatrick must have been extremely pleased with his decision to allow Reynolds's father to live among his enslaved people because the relationship resulted in many valuable enslaved girls whom he no doubt hoped would produce children in the future. Furthermore, the fact that most free people of colour who went to live among the enslaved were men also made economic

${ }^{8}$ Mrs. William Perry in Rawick, The American Slave, Supplement Series I, Volume IV, Georgia Narratives Part 2, 16.

59 Jerry Moore, Slave Narrative Project, Vol. I6, Texas, Part 3, I26-27.

60 William Scott, Slave Narrative Project, Vol. I I, North Carolina, Part 2 (Jackson-Yellerday), 264-65; Elizabeth Sparks, Slave Narrative Project, Vol. I7, Virginia (Berry-Wilson), 57.

${ }^{61}$ Mary Reynolds in Rawick, The American Slave, Supplement Series 2, Volume VIII, Texas Narratives Part 7, 3284. 
sense for slaveholders because it provided a very easy way for them to increase their supply of people to labour for them, whether enslaved or not. More rarely, though, free black women could also provide free labour alongside their children. Emma Stone, quoted at the start of this article, lived with her mother and siblings on a plantation because her mother had an enslaved spouse. Stone's situation raises specific questions about status because the children of free black women were legally free, unlike those of free black men. The slaveholder does not appear to have tried to sell Stone's mother or her children, but seemingly he acquired their labour for free and treated them as though they were enslaved. Moreover, when interviewed by the WPA, Stone described her life in a similar language to the respondents who had been enslaved, with only a scant mention of her mother being free, and said that they lived like the other enslaved people. Although her interview is fairly short, she described her plantation environment and made reference to her "missus" as if she had been enslaved herself. ${ }^{62}$

Only rarely did free status bring privileges and a sense of distinction. Callie Gray remembered a spiritual leader on her Mississippi plantation named Uncle Charlie Frazier, who would read the Bible to the enslaved people and hold prayer meetings with them. Gray described him as a free man "from Africa," with a free black wife: "His house was separate from the others and he had his own garden. He raised rice 'cause he had been use to living on it. They told him it wouldn't grow here but he showed 'em." ${ }^{3} 3$ More commonly, however, free black families, or families that straddled the slave-free divide, simply lived and worked among the enslaved, their free status sometimes uncertain, perhaps simply something people grasped just for a small sense of self-worth. Nevertheless, affective ties between the enslaved and the free meant that for some free people of colour (and occasionally Native Americans), plantation labour was preferable to being separated from their loved ones and living alone and free, especially as southern states increasingly mooted (and enacted) legislative measures to restrict the relative freedoms of free people of colour by the late antebellum era.

Slaveholder migration westwards across the US also increased opportunities for fluidity between slavery and freedom because a lack of legal infrastructure in newly acquired territories and states enabled enslavers to take advantage of free people of colour and to "shift" - albeit sometimes informally - the status of free black families to that of enslaved. Affective ties between couples again

${ }^{62}$ Emma Stone, Slave Narrative Project, Vol. I I, North Carolina, Part 2 (Jackson-Yellerday), 329-30.

${ }^{63}$ Callie Gray in Rawick, The American Slave, Supplement Series I, Volume VIII, Mississippi Narratives Part 3, 866. 
influenced black families' decisions, especially when westward movement divided up families that crossed the boundaries between bondage and liberty. For example, James Burton said his mother was enslaved, but his father a free man. Yet his father chose to travel from his home in Virginia to Copiah County, Mississippi with his mother's enslaver, where presumably he continued to live with his family among enslaved people. ${ }^{64}$ William Edward Black believed his whole family had once been free. They lived and worked for the white O'Neill family in North Carolina. However, when Rachel O'Neill married Daniel Black shortly before the Civil War, she moved with him to Itawamba County, Mississippi, taking this free black family with her. Daniel Black apparently then enslaved the family. ${ }^{65}$ William described how "he didn't feed us any too much but I didn't have to work in the field, I was a waiting boy." 66 This arrangement might well have operated at an informal level rather than being legally arranged through a "voluntary enslavement" request, especially if this took place during the upheaval and chaos of the Civil War, but it is William Black's own perception of events that is significant. He believed that people could move from freedom to slavery, and did not suggest that such a transition was outrageous or even unusual.

Slaveholders, of course, simply acquired people through whatever means they could, and when free blacks were prepared to labour in their homes, farms and plantations as though enslaved, they made a very worthy substitute indeed. Significantly, these work patterns sometimes preempted the post-Civil War regime of sharecropping in a taste of what the future held. Lu Perkins's parents bought their freedom in Mississippi before coming to Texas to work for Judge Hooker on his farm in Hunt County, although their children appear to have remained enslaved or indentured. Unsurprisingly, neither of the slaveholding Hooker families who appear on the 1860 Census in this region had free people of colour listed in their households. ${ }^{67} \mathrm{Lu}$ said her

${ }^{64}$ James Burton in Rawick, The American Slave, Supplement Series I, Volume VI, Mississippi Narratives Part 1 , 305.

${ }^{65}$ In the 1860 Census, no free people of colour are listed as living in the Black household, though since other white men did not list free blacks in their households Daniel S. Black may not have formally enslaved them. See the 1860 Federal Census, Itawamba, Mississippi, p. 50; Family History Library Film 803583 .

${ }^{66}$ William Edward Black in Rawick, The American Slave, Supplement Series I, Volume VIII, Mississippi Narratives Part 2, 143.

${ }^{67}$ James Hooker held nine enslaved people and Thomas J. Hooker held two. See "Slave inhabitants in Precinct 3, County of Hunt, State of Texas, enumerated on the 3rd September I 860," The National Archive in Washington, DC, NARA Microform Publication M432, Title: Seventh Census of the United States, I 850, Record Group: Records of the Bureau of the Census, Record Group Number 29. Cross checking these individuals against the I 860 Census reveals no free people of colour in their households. 
parents laboured "on a sharance way of doing ... he had free [blacks] and slaves," suggesting a division of any profits from their crops just as a later generation of sharecroppers typically took a quarter or a third of the value of cotton crops in the late nineteenth century. Lu herself slept in the house on a trundle bed next to her mistress just like many other young enslaved girls. She believed she was due to receive "her freedom" (presumably from apprenticeship) at age eighteen "only the war come first and set me free." 68

A child named James Grumbles also had an uncertain legal status after he "was brought" to Texas with his freed mother from Randolph County, Alabama by her former master, Jack Hamilton, in i 847 . However, his mother was jailed after "a law was passed dat all dat was called free [blacks] had to choose someone fo' a guardeen or else leave de state. De white folks said dat de free [blacks] was ruinin' de other slaves." The same day as her imprisonment, Rachel chose Aaron Burleson as her guardian and she subsequently worked on his plantation as a nurse to white children. According to the 1860 Census he appears to have owned thirty enslaved people. ${ }^{69}$ In contrast, Grumbles's uncle, Henry Perry, chose to leave Texas, and was never heard from again. Grumbles did not indicate whether he himself had been freed like his mother or whether he had remained enslaved. Nor did he say whether Burleson bought him from Jack Hamilton or whether he came "free" with his mother as an indentured child. Moreover, no such law could be found in relevant documentation for Texas. But the significant point is that, regardless of his legal status - or his perception of his legal status - on an everyday level James Grumbles's childhood was the same that of a young enslaved person. He called his mother's white guardians "Mawster Burleson" and "Mistress Jennie." He received rationed food alongside other slaves and the tone of his narrative uses the same language and common terms as enslaved people, as did some of the other free black WPA respondents included here. $7^{\circ}$

Likewise, Evie Perrin, from Copiah County, displayed some uncertainty about legal status in describing her mother's movement west:

${ }^{68}$ Lu Perkins in Rawick, The American Slave, Supplement Series 2, Volume VIII, Texas Narratives Part 7, 3054-55.

69 "Slave inhabitants in Precinct Number 3 in the County of Travis, State of Texas, enumerated on the 14th July 1860," Eighth Census of the United States I860, Series Number M653, Record Group: Records of the Bureau of the Census, Record Group Number 29.

70 James Grumbles in Rawick, The American Slave, Supplement Series 2, Volume IV, Texas Narratives Part 4, I61 5-17. See also West, Family or Freedom, i 96 n. 28. Texan laws are accessibly electronically via Gammel's Laws of Texas at the Portal to Texas History, at https://texashistory.unt.edu/explore/collections/GLT. 
My mother wasn't born in slavery. I never understood just how that came about. She came from North Carolina, and she told me many times that she was free before she came to Mississippi. My mother was smart and apt, and old Miss took her for a houseservant. One day she got mad about something what happened at the big house, so she runned off. When she couldn't be found, they hunted her with dogs. Them dogs went right straight to the ditch where my mother was hid, and before the men could get to them, they had torn off most of her clothes off her, and had bitten her all over. When they brought her in, she was a sight to see, all covered with blood and dirt. ${ }^{\text {I }}$

Perrin's mother's legal status as free did not shield her from the violence and brutality inflicted upon domestics who worked in the big house. Notably, Perrin later added that as soon as they heard about freedom "we left."72

Indeed, the westward trek also provided opportunities for whites to steal or kidnap free blacks into slavery; just as some northern people of colour were forced into enslavement against their will. ${ }^{73}$ Emma Oats believed that her family were all once free:

My folks was all free folks. When my mother died my Uncle took us - me and my brother. He hired us out and we got stole. Gene Ogleby stole us and brought us to Memphis to Joe Nivers. I reckon he sold us then. Then they stood me up in the parlor and sold me to Jack Oats. ${ }^{74}$

Just four years old at this time, Emma might have been mistaken in thinking that her family was free, or else she might have wanted to "impress" her interviewer, Irene Robertson, by telling her what she wanted to hear in order to curry favour. Yet despite these methodological concerns (which have been debated extensively by historians) her testimony is indicative of the porous boundary between slavery and freedom for free people of colour in the antebellum South, in which forced movement from freedom to slavery was a real possibility. ${ }^{75}$

${ }^{71}$ Evie Perrin in Rawick, The American Slave, Supplement Series 1 , Volume VIII, Mississippi Narratives Part 2, 988-89.

${ }^{72}$ Ibid., 990.

73 The most famous example of a free black northerner being kidnapped into slavery is Solomon Northup in Twelve Years a Slave (1853, various editions). In a case that raises more questions than it answers, WPA respondent Ambrose Hilliard Douglass claimed he was born free in Detroit in I845. His parents returned South to visit relatives "still in slavery," where they were soon "re-enslaved themselves, with their children." Slave Narrative Project, Vol. 3, Florida (Anderson-Wilson, with combined interviews of others), 104.

${ }^{74}$ Emma Oats, Slave Narrative Project, Vol. 2, Arkansas, Part 5 (McClendon-Prayer), 226. Douglas Dorsey also believed that his free parents from Maryland were captured and stolen into slavery in Florida. Slave Narrative Project, Vol. 3, Florida (Anderson-Wilson, with combined interviews of others), 96.

${ }^{75}$ Historians' discussions of the methodological issues associated with the WPA testimony is extensive. Relevant here is the fact that some respondents believed that their interviewers might be able to help them obtain federal pensions and sought to please them. But despite concerns about these sources (especially from an older generation of historians), 
At particular risk of shifting status from being free to enslaved (or treated as though they were enslaved) were black children born legally free because they had white (or Native American) mothers. Although evidence is scant, the nature of this testimony suggests that a pattern of raising these children as enslaved might well have been more common than surviving sources suggest. Because of the sensitivities surrounding the stigma of having a white mother, information of this type might simply never have been recorded, or else might have been destroyed by subsequent generations of family members. Adora Rienshaw conveyed some of her poignant family history to her WPA interviewer when explaining how her own father was born free to a white woman and an enslaved man. Apparently the wife of her grandfather's master, Rienshaw's white grandmother, had a sexual relationship with Rienshaw's grandfather, a carriage driver who belonged to her husband. He "offen seed her cry," explained Rienshaw, "an' he's talk ter her an' try ter comfort her in her troubles and dat's de way dat she come ter fall in love wid him." Their child, Rienshaw's father, was then bound out until the age of twenty-one, though she mistakenly thought that "no person wid any a drap of white blood can be a slave." 76

In fact, no child of a free white woman could legally be enslaved, but all children born to white men with enslaved women were enslaved since children followed the status of their mothers. How the binding out of her son affected Rienshaw's white grandmother remains unknown, although Rienshaw believed she had been physically beaten by her husband for the affair and for bearing another man's child. Adora Rienshaw herself claimed to have never been enslaved, describing her family as "ole issues," meaning that they were "mixed with whites," as she put it. This suggests that Rienshaw's family were all free people of colour. She closed her interview by stating, "I'm glad slavery is ober eben do I ain't neber been no slave. But I tell yo' it's bad ter be an 'ole issue'." 77

Sam T. Stewart, enslaved in Wake County, North Carolina, spoke authoritatively about intimate relationships between white women and enslaved men, but in a highly generalized way: "When a child by a Negro slave man and a white woman arrived he could not be made a slave, but he was bound out

these sources are indeed valuable - indeed unique - for exploring the everyday lives of many African Americans in the antebellum South and thereafter. Denied by law from reading and writing, oral traditions became an important vehicle for the transmission of history for these people. For recent and passionate defences of WPA evidence see Stephanie E. Jones-Rogers, They Were Her Property: White Women as Slave Owners in the American South (New Haven and London: Yale University Press, 2019), xviii-xx; and Baptist, The Half Has Never Been Told, 427-28 n. 4.

${ }^{76}$ Adora Rienshaw, Slave Narrative Project, Vol. I I, North Carolina, Part 2 (JacksonYellerday), 217-19. 
until he was 2 I years old." ${ }^{8}$ In reality, there may have been little difference between this "binding out" and enslavement. John C. Brown was raised as a slave in South Carolina, despite the fact that he believed his mother was a "white lady" who used to visit his plantation. Brown's "slaveholders" found him abandoned in a basket and then raised him as though enslaved - a slave they acquired for free. Sheton Brown, the plantation carriage driver, later told John Brown after Emancipation that he was his father. ${ }^{79}$ Sadly, these children also all grew up without the love of their biological mothers even if they were supported by wider enslaved communities and other women performing maternal roles.

Lewis Jenkins was born in Alabama to a white woman and a black father"a coachman on my master's place," he believed. He was apparently told his mother was kept hidden in an attic until Lewis's birth, presumably because of the shame this would bring upon the family. Then "they tuck me soon as I was born f'om her." The scandal compelled some of the white family to then move far away to Texas, where Lewis was raised alongside enslaved people, essentially as a slave himself. "My mastah and his family jes' lived in a log house. My mistress was my grandfather's wife and my grandmother, but I coulden claim her. Her and her oldes' chile treated me some rough." Jenkins did not convey what happened to his mother, who had her child taken away as soon as he was born. ${ }^{80}$ His tragic testimony about this separation of mother and child under a regime that divided by race illustrates the blurred nature of the divide between slavery and freedom for blacks in the antebellum South where free children of colour not only used the same language of ownership (for example, "master," "mistress") as those enslaved but often suffered, like slaves, physical and emotional violence at the hands of their white "slaveholders." Their everyday lives hence display significant parallels with those who were enslaved.

The nature of the intimate relationships between these white women and enslaved men may never be known, and the fact that these respondents emphasized the seniority of their fathers' work possibly speaks to their desire to tell their interviewers facts that they thought they wanted to hear in order to impress them. These children grew up without their mothers, either because they were relinquished voluntarily, or else because family members separated mother and child due to the stigma of raising a nonwhite child out of wedlock. For opportunistic slaveholders, free free black children in the

${ }^{78}$ Sam T. Stewart, ibid., 324.

79 John C. Brown in Rawick, The American Slave, Volume II, South Carolina Narratives Part I, I 27 .

${ }^{80}$ Lewis Jenkins in Rawick, The American Slave, Supplement Series I, Volume XII, Oklahoma Narratives, I 89-9 I. 
longer term provided valuable labour as they worked alongside the enslaved at minimal cost (as was the case for their enslaved people, enslavers provided food, shelter and clothing). Even more unusually, a free black girl with apparent Native American heritage fell into quasi-slavery, again illustrating fluidity in terms of status and complicating biracial understandings of the antebellum South. Tillie R. Powers, who had Native American ethnic characteristics, according to her interviewer, believed she had been born free in Oklahoma. She was found by the side of a road wrapped in a buffalo robe by a plantation owner named Joseph Powers. Powers then took Tillie home and raised her (with the assistance of an elderly enslaved nurse) as a slave on his plantation of around fifty people. ${ }^{81}$

Finally, for the truly desperate, the opportunity to make money out of their own free black children is one that appears to have been taken only once in WPA testimony, when Angie Garnett described a free black man, George Wright, who apparently sold his five sons into slavery for cash. "A heap of things went on," she reminisced. ${ }^{82}$ Somewhat differently, Sarah Woods Burke believed that her grandmother had been sold into slavery when she had an infant boy of just one month old (Burke's father). "some poor white people took him ter raise. He worked for them until he was a growed up man, also 'til they give him his free papers and 'lowed him to leave the plantation and come up here to the North." ${ }_{3}$ These cases display some parallels with the experiences of the Lundy children in Mississippi, as well as other impoverished and desperate free people of colour who sometimes petitioned state legislatures or county courts requesting enslavement, either for themselves or with their children, where permitted. ${ }^{84}$ Other free black parents went to orphans' courts to try to legally bind their children, presumably due to poverty. For example, in Maryland, a free black woman named Eliza Cullison tried to bind out her six-year-old daughter, Frances. A single parent, most likely impoverished, Eliza petitioned the orphans' court requesting that her daughter be bound to Maria Sanders. ${ }^{85}$

Southern state legislatures debated, and enacted, restrictive legislation designed to separate free people of colour from the enslaved and create a biracial system of free whites and enslaved blacks. But slaves and free people

${ }^{8}$ Tillie R. Powers in Rawick, The American Slave, Supplement Series 2, Volume VIII, Texas Narratives, Part 7, 3 I 43-44.

${ }^{82}$ Angie Garnett, Slave Narrative Project, Vol. I, Alabama (Aarons-Young), I 4 I-42.

${ }^{83}$ Sarah Woods Burke, Slave Narrative Project, Vol. I 2, Ohio (Anderson-Williams), I9.

${ }^{84}$ See West, Family or Freedom, chapter 3.

${ }^{85}$ Petition of Eliza Cullison, 29 July i 856, Baltimore County Register of Wills (Petitions and Orders), MSA SC 4239-18-40, Reel I1020, Schweninger Collection, Maryland State Archives, Annapolis (MSA). 
of colour formed families, homes and communities across this divide - a division often rendered meaningless on a day-to day-level-families that they fought to preserve in pragmatic ways. Many free people of colour, especially children dependent upon older people for food, shelter and other matters of sustenance, were de facto slaves in the households of white families. Ira Berlin famously described free blacks as "slaves without masters," but, ironically, some antebellum free people of colour were subjected to a kind of quasislavery with masters. ${ }^{86}$

Relatively overlooked by historians, the lives of free people of colour in the antebellum South are important not only because they provide clues about the manifestations of post-Emancipation laws and wider patterns of race relations, but also because they reveal the nuances of those race relations, as well as the development of racist thought in the era of slavery itself. During a climate of changing and ever more hostile laws directed against free people of colour, probing the experiences of those who lived on the margins of the slave regime provides a useful angle for historians interested in exploring further ties between the enslaved and free people of colour, relationships between free blacks and whites, the often desperate situation of free black children, and what these relationships reveal more broadly about interactions along the hazy, porous boundary between slavery and freedom.

\section{AUTHOR BIOGRAPHY}

Emily West is Professor of American History at the University of Reading. She is the author of Chains of Love (2004), Family or Freedom (2012) and Enslaved Women in America (2014) and is coeditor of Motherhood, Childlessness and the Care of Children in Atlantic Slave Societies (2019). She has also published numerous articles and book chapters, on slavery, gender and families in the antebellum US, including topics such as motherhood, intimate partner abuse, and wetnursing. She is grateful to colleagues at conferences, including BAAS, BrANCH, and the Commonwealth Fund Conference in American History, for their feedback on earlier versions of this work; to the readers of this article for similarly helpful critiques; and to her Reading colleague, Dr Heike Schmidt, for her comments on the draft article itself.

${ }^{86}$ This is, of course, the title of Berlin's seminal monograph of 1974 . 